\title{
JIGSAW LEARNING STRATEGY IN A DIVERSE SCIENCE-CLASSROOM SETTING: FEASIBILITY, CHALLENGES, AND ADJUSTMENT
}

\author{
Muhammad Haris Effendi-Hasibuan*, Fuldiaratman, Fatria Dewi, \\ Urip Sulistiyo, Susi Hindarti \\ Universitas Jambi, Indonesia \\ *e-mail: hariseffendi@unja.ac.id
}

\begin{abstract}
Jigsaw learning strategy is considered effective in enhancing students' learning outcomes. Yet, it is problematic for a science classroom that contains educational challenges. The aim of this study was to investigate the implementation of the jigsaw learning in science classes in Indonesian classrooms. This included the feasibility of the jigsaw strategy, the challenges that interfered with the implementations, and the necessary approach to fit the strategy with the challenges. A qualitative case study was used. Three chemistry classes (each consisted of 35 grade 11 students) and a chemistry teacher were involved in this study. Data were collected from classroom observations and interviews. The findings showed that jigsaw learning was not fully feasible as it could not be completely implemented in the participating classes. Unsupportive educational settings such as time limitation, large population, the ill-sized classroom, teacher's lack of participation and the complexity of the jigsaw structure had influenced the lack of success of the implementations. Rather than seeking help from educational supports that normally involves a financial-concern educational policy, this study recommends adjusting the jigsaw structure to increase its feasibility in such learning condition.
\end{abstract}

\section{Keywords: jigsaw learning, diverse science-classroom setting, feasibility, challenges, adjustment}

\section{STRATEGI PEMBELAJARAN JIGSAW DI KELAS SAINS YANG BERAGAM: FISIBILITAS, HAMBATAN DAN PENYESUAIAN PENERAPANNYA}

\begin{abstract}
Abstrak: Strategi pembelajaran Jigsaw efektif dalam meningkatkan hasil pembelajaran siswa. Namun, penerapannya dalam kelas sains masih menghadapi beberapa kendala. Tujuan penelitian ini adalah untuk menyelidiki penerapan strategi pembelajaran jigsaw pada pelajaran sains di kelas di Indonesia. Penyelidikan meliputi fisibilitas penggunaan jigsaw, hambatan yang dihadapi dalam penerapannya, dan upaya penyesuaian model ini agar dapat diterapkan dengan baik. Desain studi kasus kualitatif digunakan dalam penelitian ini. Tiga kelas kimia (masing-masing berisi 35 orang siswa kelas 11) dan seorang guru kimia terlibat dalam penelitian ini. Data dikumpulkan menggunakan observasi kelas dan wawancara. Hasil penelitian menunjukan bahwa penerapan jigsaw tidak sepenuhnya terlaksana dengan baik sebagaimana ditunjukan dari penerapan model ini di ketiga kelas tersebut. Lingkungan belajar yang tidak mendukung seperti keterbatasan waktu, jumlah siswa yang banyak, kelas yang sempit, kurangnya bimbingan dari guru dan tahapan jigsaw yang kompleks merupakan faktor yang mempengaruhi keberhasilan penerapan model pembelajaran ini di dalam kelas. Alih alih meminta dukungan dari pihak terkait yang biasanya melibatkan kebijakan yang berhubungan dengan masalah anggaran, penelitian ini merekomendasikan penyesuaian struktur pembelajaran jigsaw untuk meningkatkan fisibilitas penerapannya menyesuaikan dengan kondisi belajar yang ada.
\end{abstract}

Kata Kunci: model pembelajaran jigsaw, kelas sains yang beragam, fisibilitas, hambatan, penyesuaian

\section{INTRODUCTION}

Widely known, the jigsaw is a learning strategy that involves students to learn in five steps of learning. These include the steps of introduction, first home-group-discussion
(HGD), expert-group-discussion (EGD), second HGD, and review (Aronson, Blaney, Stephan, Sikes, \& Snapp, 1978). Students are encouraged to do peer tutoring, share ideas, and perform discussions in order to promote their ability of 
working cooperatively (Joyce, Weil, \& Calhoun, 2009; Mengduo \& Xiaoling, 2010). Students' learning achievements are expected to increase when they are learning using cooperative learning, especially the jigsaw strategy.

Extensive studies about jigsaw learning had been conducted to investigate its effectiveness in providing students with varied learning outcomes. Jigsaw had been effective in developing students' argumentation skills (Effendi-Hsb, Harizon, Ngatijo, Fuldiaratman, \& Sulistyo, 2019), activity and creative thinking ability (Li, 2012), pedagogical knowledge and communication skill (Halimah \& Sukmayadi, 2019), and collaborative skills and learning motivation (Fernandez-Rio, Sanz, FernandezCando, \& Santos, 2017; Tombak \& Altun, 2016; Ural, Ercan, \& Gençoğlan, 2017). Jigsaw had also been successful in enhancing students' participation and enthusiasm in learning (Maceiras, Cancela, Urréjola, \& Sánchez, 2011; Mengduo \& Xiaoling, 2010), confidence and enjoyment to learn ( $\mathrm{Li}, 2012)$, responsibility for topic-to-learn, and even jigsaw had been effective in reducing students' anxiety in learning science (Oludipe \& Awokoy, 2010).

Research about jigsaw learning had also been performed to generate its variants to provide diverse learning experiences and advantages. Slavin (1987) had modified the jigsaw I of Aronson becoming the jigsaw II by adding competition and reward phase. Stahl (1994) had designed Jigsaw III with a cooperative test review process that included a homegroup reconvene phase and a process-review phase. Holliday (2002) had designed jigsaw IV consisting of nine steps and producing increased students' conceptual understanding. Hedeen (2003) had used reversed jigsaw in science learning by excluding the second mixed group (second HGD) to promote students' dialogue and cooperation. Doymus (2007) had used subject jigsaw to develop students' chemistry understanding. Persky \& Pollack (2009) had developed a hybrid jigsaw that incorporated routine learning activities with the self-selected expert group and found that the students had obtained developed knowledge about the learned concepts. More recently, Zubaidah, Corebima, Mahanal, \& Mistianah (2018) had designed and used a remapping jigsaw that consisted of steps of reading, making of concept map, and modelling activity to equip students with adequate preconceptions about the topicto-discuss producing a more efficient learning activity. These evidence confirmed that jigsaw learning offers great potentials in effectively helping students learn the respected subjects.

Because of its potentials, jigsaw learning and its modified versions have been used in educational settings more frequent than the other types of cooperative learning strategies (Jansoon, Somsook, \& Coll, 2008). Jigsaw learning had been used in the primary, secondary, and university levels (Artut \& Tarim, 2007). Jigsaw had been implemented in the science subjects such as chemistry (Doymus, 2007; EffendiHasibuan, Bakar, \& Harizon, 2020), pharmacy (Persky \& Pollack, 2009), mathematics (Leikin \& Zaslavsky, 1999), and statistics (Perkins \& Saris, 2001). Moreover, jigsaw had been applied in social-science subjects such as English (Li, 2012). Those global adoptions affirm that jigsaw learning is popular with a frequent use in learning activities.

However, to take maximal advantages from the jigsaw, a successful implementation is required. On the other hand, constraints play a significant role in influencing the success of a cooperative learning implementation particularly in a developing country due to its educational challenges (Effendi-Hasibuan, Harizon, Ngatijo, \& Mukminin, 2019), and these also apply to the jigsaw learning. Jansoon et al. (2008) had identified that jigsaw learning in Thailand had been influenced by time, students' understanding, and teachers' understanding of the jigsaw process. Li (2012) had identified that jigsaw learning in an English classroom in China had been affected by time, teachers' participation to provide guidance, populated classroom, and classroom setting. Similarly, Rika (2017) had reported that jigsaw learning in an English classroom in Indonesia had been interfered by the lack of time and teachers' classroom management skills. These descriptions revealed a phenomenon which suggested that the implementation of jigsaw learning in those countries was challenging. The problems might be from the ill-suited educational settings which created a situation for the jigsaw to be less feasible.

To clarify this feasibility issue, we looked further to the literature. However, little is known 
about the feasibility of jigsaw learning in developing countries. This includes the dearth of information about how to bring about the jigsaw in such learning conditions. Given the facts, one may assume that there is a deficiency in the literature concerning those informations. Such shortages might happen because the focus of researches on the jigsaw learning -for decades- have mainly directed to look at the effectiveness of the jigsaw and its derivatives on students' learning outcomes (see all the above mentioned articles). Meanwhile, little attention had been paid to look at how compatible the jigsaw learning would be in diverse educational backgrounds, what challenges that may hamper the jigsaw implementation, and what possible solutions that might be taken to optimize the practicability of the jigsaw in such learning conditions. We thus argue that this literature deficiency needs to be addressed to provide a broader understanding of jigsaw learning.

Aiming to understand the jigsaw feasibility in a constraint-infested learning condition as well as to contribute to the body of knowledge, therefore, an investigation needs to be carried out. The constraints that may affect the success of the jigsaw implementation need to be identified and adjustments that would make the jigsaw more compatible with the learning conditions need to be formulated. The importance of taking into account the learning conditions including constraints for a successful jigsaw implementation had been resounded by Li (2012). This author stated that to implement a cooperative learning strategy like the jigsaw successfully thus the conditions of learning need to be concerned. Otherwise, a limited success of this learning strategy implementation will be gained when such condition is ignored (Jansen, 1998). Therefore, based on the above descriptions, this research aims to investigate the practicability of jigsaw learning and challenges that affected the utilization in a developing country like Indonesia. This research also aimed to identify possible adjustments that would make the jigsaw more compatible with the conditions.

\section{METHOD}

This study was conducted in 2019 in a Jambi Secondary School (JSS) in Indonesia. A case study research design involving a qualitative approach was used in this study. A case study research is conducted when a researcher wants to obtain understanding about activities, events, process consisting of steps, or implementation of a program. A case study may involve an individual, several individuals or groups (Creswell, 2012). In this study, a case study research design was used to understand how a class of students and a teacher implemented the jigsaw learning in the concept of hydrocarbon substances in chemistry.

Three regular classes of 11th grade (each 35 students aged 15-16 years old) were thus recruited to be the participants of this study. A consent form was obtained from the school authority ensuring the involvement and exposure of the students. One chemistry teacher named Farah (pseudonym), a female in her 40s, held a master degree in chemistry education, and with more than 20 years of teaching experience also participated in this study. Prior to the conduct of the study, this teacher had joined a two-week workshop about the jigsaw learning to ensure her knowledge and skill in implementing this teaching strategy. The results of the workshop will be reported in a separate article.

The basis of this study was the Jigsaw I. The students were encouraged to use this learning strategy in 90 minutes to learn about a topic in chemistry, particularly about the different types of hydrocarbon substances which was recommended by curriculum for $11^{\text {th }}$ grade students (Permendikbud RI 2018 No. 37). These included the substances of alkane (single-bond hydrocarbon), alkene (doublebond hydrocarbon), and alkyne (triple-bond hydrocarbon). Five different tasks were then assigned to which students needed: 1) to identify the names of given alkanes, alkenes, and alkynes substances (task 1 or T1); 2) to provide correct names for given alkanes, alkenes, and alkynes substances (T2); 3) to draw the isomers (ions/ molecules with identical formulas but are distinctive in structures) of given alkanes substances (T3); 4) to draw the isomers of given alkenes substances (T4); 5) to draw the isomers of given alkynes substances (T5). The details of the lesson plan are described in Table 1.

Two protocols (i.e., observation \& interview) had been used to help collecting the data. According to Creswell (2012) the use of observation is to collect details and to build a complete portrait of an event while the use 
Table 1. The Lesson Plan of Hydrocarbon in the Jigsaw I Learning

\begin{tabular}{ll}
\hline Steps & Learning Activities (90 minutes) \\
\hline 1. Introduction & - The teacher delivered the materials of hydrocarbon substances \\
2. First HGD & - Each student learned one task in 7 HGD (5 students each) \\
& - HGD-1 consisted of students of A1, A2, A3, A4, and A5. A1 learned T1, A2 \\
& learned T2, A3 learned T3, A4 learned T4, and A5 learned T5 \\
& - Same administrations were also applied to the HGD-2 to the HGD-7 \\
& - The students discussed the same task in 5 EGD (7 students each) \\
3. EGD & - EGD-1 consisted of students A1, B1, C1, D1, E1, F1, and G1 who learned T1 \\
& - Same administrations were also applied to the EGD-2 to the EGD-5 \\
4. Second HGD & - The students returned to the HGD. Each student explained the task that he/she \\
& had mastered from the EGD to the peers \\
5. Review & - The students were engaged in a classroom discussion to consult and to verify \\
& whether what he/she had known were already correct
\end{tabular}

of interview is to obtain data that support the observational data. In this study, the observation was conducted using fieldnote style aimed to record all the events during the jigsaw learning. This includes data about the practicability of the jigsaw learning, the challenges the students faced during the lessons, and the critical points of the implementation that needed adjustments. The observations were carried out once in three different classes for 90 minutes each.

In addition, the interview of this study was conducted with the teacher at the end of the study to collect her confirmation towards the observed learning events. Therefore, the interview questions were constructed after the findings from the observations were finalized. Based on the results of the observations (Appendix 1), 8 open questions $(\mathrm{Q})$ emerged to be the interview items. These included 7 questions which asked about the challenges the students faced during the lessons (the complexity of the jigsaw structure, time limitation, classroom population, classroom space/size, the teachers' participation to give guidance) and 1 question which asked about the teacher's feedback towards the current feasibility of the jigsaw as well as the future use of the jigsaw in Indonesia. The questions were constructed in the semi-structured interview style where the researcher could paraphrase the questions during the interview to provide clarity for the teacher. The questions (Q) are as follow.

Q1: Do you see that the structure of jigsaw is complex and difficult to use? Why?
Q2: Do you see that the HGD and EGD are difficult for your students to carry out? Why?

Q3: Do you see that the steps are so many that students need more time to complete? Why?

Q4: Have your students been challenged by the time limitation?

Q5: Have your students been challenged by the number of students?

Q6: Do you see that the size of the classroom had been a challenge in the jigsaw learning?

Q7: Have you guided your students in the jigsaw learning? Why?

Q8: Do you have any opinion about the jigsaw feasibility in your classrooms and suggestions for its future use?

The data from the fieldnote observations were analyzed using basic qualitative analysis technique using interpretive method towards the learning events. This aimed to make sense on the run of the jigsaw learning and to look for the themes of constraints. Meanwhile, the data from the interviews were analyzed using the descriptive method on the teacher's answers. This was achieved by looking at significant statements of the teacher on the run of the lesson, the constraints, and future use of the jigsaw learning in her school. Finally, the validity of the data analysis process was achieved by involving the member-checking process, peer-discussions amongst the researchers, and the triangulation technique (Creswell, 2009). 


\section{FINDINGS AND DISCUSSION Findings}

Based on the results of observations, it is seen that the students in the three observed classrooms shared similar experience in using the jigsaw. At the beginning of the lessons (step 1), Farah started the lessons by explaining the content. She described the jigsaw and its steps. She distributed the five tasks including $\mathrm{T} 1$ to T5 then assigned the students in 7 HGD with 5 students each. During the first HGD (step 2), the students worked on the individual task in good order. They initially learned the tasks independently but then they started to talk about the tasks. Meanwhile, Farah supervised the students from the front of the class. When the time was up, she assigned the students in 5 EGD with 7 students each. She instructed the students to collect themselves in the EGD but the condition was very chaotic as the students were shouting to collect their peers to form the EGD (step 3). The students looked confused to collect their peers in the EGD. In each EGD, one student led the discussion. The leader explained the solution of the task and the other students responded. However, not all the EGD members understood the solution easily. Thus, the group need iterations to make the 7 students understood and that took much time to complete. Similarly, Farah stayed at the front of the class supervising the students.

Then, when the time for the EGD was up, Farah instructed the students to return to the HGD (step 4). Again, the condition was very chaotic as the students were shouting to collect their peers to return to HGD. In this second HGD, another student led the discussion in each group. The students took turns to explain their individual tasks to the peers but not every student understood all the 5 tasks easily and promptly. As a result, the explanations required many iterations and longer time to complete. Farah only visited some groups that were close to her. Unluckily, when the students were busy discussing the 5 tasks in the second HGD, the 90-minute time was up. Consequently, Farah needed to stop the lesson immediately as another teacher was coming. The students were urged to stop the HGD discussions; in fact, they had not yet started the review process (step 5). They had not had opportunities to consult and verify whether or not their answers for the 5 tasks were correct.

Based on the description and data in Appendix 1, it was seen that jigsaw learning was not feasible in the three classes. The jigsaw learning was unsuccessfully implemented up to the fifth step. Rather, this was only usable up to the fourth step. Even the students needed more than 90 minutes to complete the jigsaw from step 1 to the step 4. It is seen that the students of class A needed 95 minutes, the students in the class B needed 93 minutes, and the students in the class $\mathrm{C}$ needed 96 minutes to complete the lessons. As a result, the fifth step was undone due to the time limitation.

Based on the results of observations, it is also seen that five constraints had challenged the jigsaw implementation. The constraints included the complexity of the jigsaw structure, the time limitation, the large classroom population, the ill-size of the classroom, and the teacher's lack of participation to guide the students. These constraints were identified during the observations in the three classes and presented in Appendix 1.

The results of observations were parallel with the results of interview conducted with Farah at the end of the research. Based on her responses (R) towards the interview questions, it is seen that Farah agreed that the jigsaw learning was not feasible for the three observed classes (R8). Farah also agreed that the implementation had been hampered by the five constraints. These were the complexity of the jigsaw structure (R1), the complexity of the home group discussion (HGD) and expert group discussion (EGD) (R2), the many steps of jigsaw (R3), the time limitation (R4), the number of the students which was over populated (R5), the size of the classroom which was not supportive for the jigsaw learning implementation (R6), and the low guidance of her delivered to the students during the lessons (R7). Finally, Farah suggested that adjustments were needed for the jigsaw to make it usable for schools in Jambi Indonesia, particularly in her schools (R8). The results of the interview are summarized in Table 2. 
Table 2. Results of Interview

\begin{tabular}{|c|c|c|}
\hline Questions & Tea & hers' Summarized Response (R) \\
\hline Q1 & $\mathrm{R} 1$ & $\begin{array}{l}\text { Yes, jigsaw has a complicated structure [the home-group discussion, the expert- } \\
\text { group discussion, another home-group discussion] and difficult to use. }\end{array}$ \\
\hline Q2 & $\mathrm{R} 2$ & $\begin{array}{l}\text { Certainly. These discussions [HGD and EGD] were difficult for all my students } \\
\text { to use. They needed to have a good understanding of the use of each of the } \\
\text { discussion. }\end{array}$ \\
\hline Q3 & R3 & $\begin{array}{l}\text { Sure, the steps are so many. The jigsaw needed more than } 90 \text { minutes for full } \\
\text { implementation [ } 5 \text { steps]. }\end{array}$ \\
\hline Q4 & $\mathrm{R} 4$ & $\begin{array}{l}\text { Yes, the time limitation very clearly prohibited the students to be successful } \\
\text { implementing the jigsaw. }\end{array}$ \\
\hline Q5 & R5 & $\begin{array}{l}\text { Of course. They looked confused about collecting their peers due to the large } \\
\text { population of the classroom. They were also tired in making consensus [in EGD } \\
\text { and second HGD] for the answers of the tasks due to this crowded situation. }\end{array}$ \\
\hline Q6 & R6 & $\begin{array}{l}\text { Absolutely. The size of the classroom was only } 7 \times 8 \text { meters for the } 35 \text { students } \\
\text { and that was not fit for the high mobility of the students between the HGD, } \\
\text { EGD, and second HGD. This [the classroom] should be bigger to support the } \\
\text { students' interactions and movements. }\end{array}$ \\
\hline Q7 & R7 & $\begin{array}{l}\text { No, I did not. There were } 35 \text { [students] in the ill-size classroom. I could not } \\
\text { manage to do that. }\end{array}$ \\
\hline Q8 & $\mathrm{R} 8$ & $\begin{array}{l}\text { I believe that the jigsaw does not fit the learning situations in my school. I think } \\
\text { the structure should be simpler to make it more usable here. }\end{array}$ \\
\hline
\end{tabular}

\section{Discussion}

Based on the data in Appendix 1, it was seen that the students in the three observed classrooms were struggling to implement the jigsaw due to the complexity of the jigsaw structure. They were confused to conduct the lesson. Their confusion was started when they were instructed to form the EGD (step 3) and the second HGD (step 4).

Actually, at the beginning of the lesson, the students conducted the first HGD (step 2) without any difficulties as this step is similar to the step of other cooperative learning strategies -such as discovery learning- that consists of only one step of discussion that they were familiar with. They looked manage to form and conduct the first HGD in good order.

However, when they were instructed to break the first HGD to form the EGD (step 3 ) they produced noises as they were shouting to collect their peers to make the group. They seemed in confusion about how to collect peers in order. Furthermore, during the EGD, the students looked puzzled with the purpose of the EGD. This situation continued when they were instructed to break the EGD and returned to the HGD (step 4) to discuss all the five tasks.
They again made noises as they were shouting to call their peers. They looked curious about the learning mechanism. The students looked very confused as they did not understand the complexity of the learning mechanism that made the jigsaw strategy difficult for them. The complexity of the jigsaw was admitted by Farah in her responses (R1, R2, R3) in the interview (see Table 2). This condition was parallel with the result of Jansoon et al. (2008) who had also identified that students' understanding of jigsaw had challenged the jigsaw learning in Thailand. Balfakih (2003) reckoned that a good understanding of the process of a cooperative learning strategy determines the success of its implementation.

Based on the data in Appendix 1, it was also seen that the implementation of the jigsaw in the three observed classes had been seriously constrained by the time limitation. It was seen that the given time (90 minutes) was insufficient for the full conduct of jigsaw learning. The students of the three classes were unable to complete the lessons from the introduction (step 1) to the review process (step 5). This phenomenon was supported by Farah's response (R4) in the interview (see Table 2). Jansoon et al. (2008) 
had also identified time limitation as a constraint in the jigsaw learning in Thailand. Colosi \& Zales (1998) affirmed that time limitation has been a barrier to a constructivist-driven learning process like the jigsaw.

Unluckily, the time limitation brought disadvantages for the students. When the full time (90 minutes) was up, the learning process must be stopped at the step four wherein the students were running the second HGD. The forcefully-stopped lesson like that absolutely gave disadvantages for the students as they did not have opportunities to conduct the classroom discussions/review process. In fact, the review process or classroom discussion step is a very important step for the development of the students' conceptual understanding. According to the Gagne's nine events of learning that this learning step is compulsory to be conducted in any lesson. Gagne called this as the step of providing feedback (Gagne, Briggs, \& Wager, 1992). This step was crucial for the participant students to confirm whether they had already attained the correct knowledge and/or performance; in this case, it was about the understanding of the hydrocarbon substances.

Based on the data in Appendix 1, it is seen that the incomplete jigsaw implementation had also been influenced by the populated classroom. The students in the three classrooms looked very hard to collect their peers orderly. They were shouting to call their peers to group in all the types of discussions due to the classroom population that reached up to 35 students.

The effect of a large number of students on the success of the jigsaw implementation was observed in the conduct of EGD (Appendix 1). Since each EGD consisted of 7 students who needed to discuss the same task, thus each EGD was challenged to make all the 7 students understood about the task. Furthermore, the same phenomenon was also observed in the conduct of the second HGD. Since there were 5 students who needed to understand the 5 tasks, the group was seriously challenged to make all the 5 students understand the 5 different tasks. Therefore, to find a consensus about the solution of the tasks, the students had spent a lot of time and hard efforts. This situation might also have consumed lots of energy of the students to conduct jigsaw learning in such a populated classroom. Those situations were admitted by
Farah in the interview (R5).

The overpopulated classroom that influenced the success of jigsaw learning indicated that the jigsaw strategy may not fit with the classroom population regulation which is nationally employed in Indonesia. In this regulation, each classroom is prescribed to be fulfilled by 35 students. This regulation is becoming more compulsory for the national state schools in Indonesia like the participant school (JSS) as this school is obliged to enroll lots of junior high school graduates in the secondary education degree.

In addition, the incomplete jigsaw implementation had also been influenced by the size of the classroom. Based on the observation, it was seen that the size of the classroom which was $7 \times 8$ meter was ill-fit for the 35 students to do high mobilities. One could argue that the size of the classroom was normal but in our opinion that it was only acceptable for a learning activity that did not engage students to make high mobility of discussions. However, in a learning situation that engaged students to do many movements involving the movement of tables and chairs, such classroom size was highly inappropriate. Such a situation was certainly brought a very crowded situation when the students needed to move from HGD to EGD and vice versa. Responding to this issue, Farah shared her opinion regarding the effect of the classroom size on the effectiveness and efficiency of the discussions. When she was asked whether the size of the classroom had challenged her students in the jigsaw learning (R6) she showed her agreement (see Table 2).

Finally, the incomplete jigsaw implementation had also been influenced by Farah's participation to guide the students. Based on the data in Appendix 1, it was seen that Farah had only provided minimal guidance during the lessons. She mostly stayed at the front of the class instead of visiting groups. However, this teacher's minimal guidance was affected by the classroom population and size. During the lessons, it was seen that Farah looked confused in finding a way between the tight formation of tables and chairs -which were arranged so closely between one and another- to reach the students. The tight configuration of the tables and the chairs was due both to the large number of students and the inappropriate-size of the classroom. Then, in the interview, Farah 
admitted that she did not go around providing guidance as she found it difficult to do so (R7).

All the five constraints that had brought the unsuccessful implementation of the jigsaw affirm that this learning strategy was not feasible in the Indonesia educational settings. These constraints, however, are actually not surprising as these are prevalent in Indonesia. Previous studies had identified similar constraints that influenced the low viability of the inquiry-based learning (IbL) -another type of cooperative learning strategy- in some areas in this country. These included time limitation, learning facilities such as classrooms and laboratory, a large number of students, teachers' competency in using the IbL (Effendi-Hasibuan et al., 2019), and teachers' beliefs on the importance of the IbL (Effendi-Hasibuan, Ngatijo, \& Sulistiyo, 2019). The obstacles observed for the jigsaw, however, were actually not only belongs to Indonesia. As described before, similar problems in the use of jigsaw learning strategies had been resounded by Li (2012) in China and Jansoon et al. (2008) in Thailand. These included the time limitation, teachers' participation to provide guidance, the populated classroom, the classroom layout with fixed chairs and tables, and students' minimal understanding of jigsaw. These findings, therefore, inform that the challenges in the use of the jigsaw were prevailing in some developing countries. These challenges should be concerned with science teachers and thus need to be adapted to produce a successful jigsaw implementation in such educational conditions.

Based on the results of the observations (Appendix 1), it was seen that the success of jigsaw learning was affected by two types of challenges. These were the process-related challenge that involved the complexity of the jigsaw mechanism and the situation-related challenge that involved the ill-suited learning supports (see Figure 1).
The process-related challenge stood for the multi-level discussions that involved the steps of HGD, EGD, and second HGD. Based on the findings, it was seen that these learning steps had made the students in confusion to conduct the jigsaw. These steps had made the jigsaw a complex strategy and probably provided extra burden for the students to accomplish. Sweller, Ayres, \& Kalyuga (2011) called this complexity as the extrinsic/extraneous cognitive load/burden; the cognitive load that comes from the external factors (i.e., the learning process difficulty) which is different from the intrinsic cognitive load that comes from the internal factors (i.e., the content difficulty). To successfully implement the jigsaw, thus, the students had been drawn to use a bigger portion of their mental efforts to deal with the learning mechanism. Paas, Tuovinen, Tabbers, \& van Gerven (2003) defined mental efforts as 'the aspect of cognitive load that refers to the cognitive capacity that is actually allocated to accommodate the demands imposed by the task: thus, it can be considered to reflect the actual cognitive load'.

These may include the students' attention, concentration, and cognitive ability. This means that, in that situation, the students were forced to allocate more of their attention, concentration, and cognitive ability to conduct the high mobility learning activity from one discussion to another discussion and unconsciously assigned their remaining attention, concentration, and cognitive ability (less in portion) to apprehend the new understanding of the chemistry contents. In shorts, the students had paid mental efforts more on the learning process than on the chemistry contents. The complexity of such learning process that had distracted the students' focus from acquiring new knowledge and performance to exercising the learning mechanism will certainly gave disadvantages for the development of the students' conceptual

\begin{tabular}{|c|c|c|}
\hline \multirow{3}{*}{$\begin{array}{l}\frac{\text { Process-related }}{\text { challenge: }} \\
\text { Complexity of the Jigsaw }\end{array}$} & & \multirow{4}{*}{$\begin{array}{c}\text { Situation-related challenge: } \\
\text { Ill-suited learning supports } \\
\text { (time, classroom population, } \\
\text { classroom size, teacher's } \\
\text { participation to guide) }\end{array}$} \\
\hline & jigsaw learning in a & \\
\hline & & \\
\hline & & \\
\hline
\end{tabular}

Figure 1. The Two Types of Challenges in the Jigsaw Learning 
understanding (Chandler \& Sweller, 1991; 1992), in this case is about the concepts of hydrocarbon substances.

Supports are needed to minimize the excessive burden/load generated from the difficult learning process (the extraneous cognitive load). Chandler \& Sweller (1991; 1992) argued that reasonable learning time is the important key that could positively impact the reduction of such cognitive load. The other keys may include the considerable learning space (classroom population and suitable-sized classroom) and the involvement of the teacher to guide. Unfortunately, these supports did not present during the implementations. Consequently, once again, the students were forced to use more of their mental efforts to conduct the jigsaw mechanism with large number of peers, in an ill-fit classroom space, and under limited time and minimal guidance. This situation had also caused the distraction of the students' focus from understanding the chemistry concepts to implementing the learning mechanism under the absence of those supports. The absence of those supports which we previously called as the situation-related challenge might have created another extra burden/load for the students to deal with. These challenges had made the complexity of the jigsaw learning getting more severe.

The discussion which present evidence about the role of a difficult learning process and ill-fit learning supports in affecting the success of jigsaw learning may have informed an important knowledge for the jigsaw-related literatures. The findings revealed that those challenges which provided extra burden/load might have created a situation for the students of not finishing the learning process and more severe of not taking advantages from the learning activity. Sweller et al. (2011) had reckoned that the increased cognitive burden/load may threaten the acquisition of learning goals. This is why such a complex learning process and ill-fit learning supports should be avoided and removed from a classroom activity.

Aiming to make the jigsaw learning more applicable in Indonesia, adjustments towards the situations of learning are needed to take. These include the provision of the more sufficient time that makes the students less pressured to conduct all the steps, the reduction of the classroom population that creates a more ordered and spacy learning situation, the building of new classrooms that fit the number of students, and the development of the teacher's skills in giving guidance and that of awareness of taking participation in the such cooperative learning activity. The improvement of those learning supports is important for a better jigsaw learning implementation in this area. However, such learning supports fulfilment requires a big educational policy at the national level by the Indonesia authorities that could not be undertaken at a quick pace.

Alternatively, reducing the complexity of the jigsaw structure can be a reasonable breakthrough for the future success of the implementation. This can be achieved by simplifying the complex structure of the jigsaw to be a simpler one. Based on the results of the observations (Appendix 1), it was seen that the jigsaw needed only 4 steps instead of 5 . Responding to this demand, this article introduces four-step jigsaw (4SJ) learning - a simpler structure of jigsaw- that includes only 4 steps i.e., introduction, focus group discussion, share group discussion, and classroom discussion/ review (see Figure 2). In our related research, we have seen that $4 \mathrm{SJ}$ is more applicable to Indonesia's science classes. The details of the 4SJ learning, its feasibility, and its effect on Indonesia students' learning outcomes will be presented in our next article.

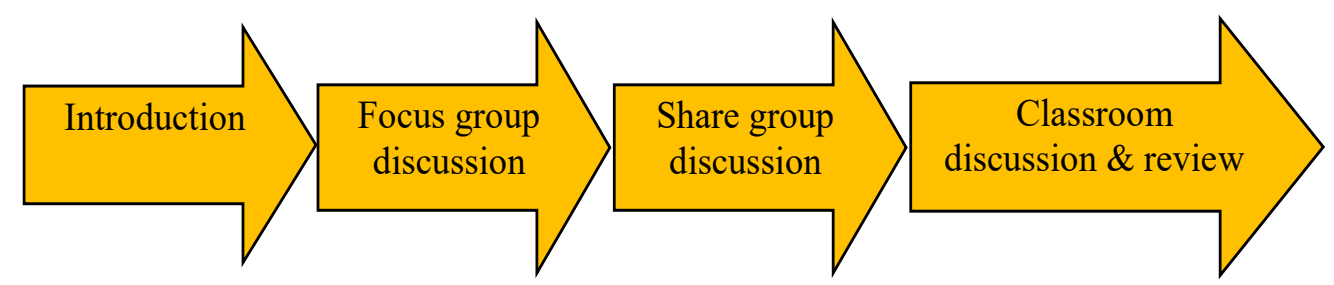

Figure 2. The Structure of Four-step Jigsaw (4SJ) Learning 
The demand to find the adjusted structure of cooperative learning strategies -such as the jigsaw- was essentially not a new idea. Previous authors (Anderson, 2002; Furtak, 2006; HmeloSilver, Duncan, \& Chinn, 2007) had already recommended this need on purpose to increase the maximal implementation of these strategies in science learning in developing areas, and this includes Indonesia. This need had also been addressed by Farah in the interview when she was asked to provide feedback and reflection about the jigsaw learning (R8). She said that the jigsaw does not fit the learning situations in her school. The structure is complicated for her students. So, she supposed that the jigsaw structure should be simpler to make it more applicable in her classroom.

\section{CONCLUSION}

Based on the results of the research and discussion, it can be concluded that jigsaw learning was not feasible and fully implemented in the chosen science classrooms. Some constraints had influenced the implementation. These included the challenges that related to learning process (i.e., the complexity of the jigsaw) and the challenges that related to the learning situation (i.e., the time limitation, the classroom population, the classroom facilities, and the participation of the teacher to guide the students). To increase its feasibility in Indonesia, the structure of jigsaw needs to be simplified. Thus, this current study had designed 4SJ with only 4 steps. This adjustment is more reasonable to take rather than expecting learning supports that depend on the national educational policy. Future research needs to be carried out to investigate the effectiveness of the 4SJ in helping students develop their learning outcomes in science classes. The findings of this study had provided important knowledge for the literatures about the practicability, challenges, and adjusted form of jigsaw in a developing country in a way to present a complete portrait of jigsaw learning as an effective learning strategy. Finally, the results of the research would provide important information for teachers in other developing countries about how to bring about jigsaw learning in their challenge-contaminated conditions.

\section{ACKOWLEDGEMENT}

We thank the Directorate of Higher Degree the Ministry of National Education of the Republic of Indonesia for the supports that had been given for the conduct of this study.

\section{REFERENCES}

Anderson, R. D. (2002). Reforming science teaching: What research says about inquiry. Journal of Science Teacher Education, 13(1), 1-12. https://doi. org/10.1023/A:1015171124982.

Aronson, E., Blaney, N., Stephan, C., Sikes, J., \& Snapp, M. (1978). The jigsaw classroom. Beverly Hills, CA: Sage Publishing Company.

Artut, P.D., \& Tarim, K. (2007). The effectiveness of jigsaw II on prospective elementary school teachers. Asia-Pacific Journal of TeacherEducation, 35(2), 129-141. https:// doi.org/10.1080/13598660701268551.

Balfakih, N. M. A. (2003). The effectiveness of student team-achievement division (STAD) for teaching high school chemistry in the United Arab Emirates. International Journal of Science Education, 25(5), 605-624. https://doi. org/10.1080/09500690110078879.

Chandler, P., \& Sweller, J. (1991). Cognitive load theory and the format of instruction. Cognition and Instruction, 8(4), 293-332. https://doi.org/10.1207/ s1532690xci0804_2.

Chandler, P., \& Sweller, J. (1992). The splitattention effect as a factor in the design of instruction. British Journal of Educational Psychology, 62(2), 233-246. https://doi. org/10.1111/j.2044-8279.1992.tb01017.x.

Colosi, J. C., \& Zales, C. R. (1998). Jigsaw cooperative learning improves Biology Lab Courses. BioScience, 48(2), 118-124. https://doi.org/10.2307/1313137.

Creswell, J. W. (2009). Research design: Qualitative, quantitative, and mixed methods approaches $\left(3^{\text {rd }}\right.$ ed). California, CA: Sage Publication. 
Creswell, J. W. (2012). Educational research: Planning, conducting and evaluating quantitative and qualitative research $\left(4^{\text {th }}\right.$ ed). Boston, MA: Pearson Education Inc.

Doymus, K. (2007). Effects of a cooperative learning strategy on teaching and learning phases of matter and one-component phase diagrams. Journal of Chemical Education, 84(11), 1857-1860. https:// doi.org/10.1021/ed084p1857.

Effendi-Hasibuan, M. H., Bakar, A., \& Harizon, H. (2020). Skills to argue: Using argumentbased learning (AbL) and socio-scientific issues to promote university students' argumentation skills in chemistry. Journal of Physics: Conference Series, 1567(2), 1-7. https://doi.org/10.1088/17426596/1567/2/022042.

Effendi-Hasibuan, M. H., Harizon, H., Ngatijo, N., \& Mukminin, A. (2019). The inquirybased teaching instruction (IbTI) in Indonesian secondary education: What makes science teachers successful enact the curriculum? Journal of Turkish Science Education, 16(1), 18-33. https:// doi.org/10.12973/tused.10263a.

Effendi-Hasibuan, M. H., Ngatijo, N., \& Sulistiyo, U. (2019). Inquiry-based learning in Indonesia: Portraying supports, situational beliefs, and chemistry teachers' adoptions. Journal of Turkish Science Education, 16(4), 538-553. https://doi. org/10.36681/tused.2020.6.

Effendi-Hsb, M. H., Harizon, H., Ngatijo, N., Fuldiaratman, F., \& Sulistyo, U. (2019). Promoting Indonesian secondary school students' argumentation skills in the concept of chemistry reactionrate: A comparative effect of three cooperative learning strategies. Journal of Physics: Conference Series, 1317(1), 1-13. $\quad$ https://doi.org/10.1088/17426596/1317/1/012143.

Fernandez-Rio, J., Sanz, N., FernandezCando, J., \& Santos, L. (2017). Impact of a sustained cooperative learning intervention on student motivation. Physical Education and Sport Pedagogy,
22(1), 89-105. https://doi.org/10.1080/17 408989.2015.1123238.

Furtak, E. M. (2006). The problem with answers: An exploration of guided scientific inquiry teaching. Science Education, 90(3), 453467. https://doi.org/10.1002/sce.20130.

Gagne, R. M., Briggs, L. J., \& Wager, W. (1992). Principles of instructional design ( $\left.4^{\text {th }} \mathrm{ed}\right)$. USA: Harcourt Brace College Publishers.

Halimah, L., \& Sukmayadi, V. (2019). The role of "jigsaw" method in enhancing Indonesian prospective teachers' pedagogical knowledge and communication skill. International Journal of Instruction, 12(2), 289-304. https://doi.org/10.29333/ iji.2019.12219a.

Hedeen, T. (2003). The reverse Jigsaw: A process of cooperative learning and discussion. Teaching Sociology, 31(3), 325-332. https://doi.org/10.2307/3211330.

Hmelo-Silver, C. E., Duncan, R. G., \& Chinn, C. A. (2007). Scaffolding and achievement in problem-based and inquiry learning: A response to Kirschner, Sweller, and Clark (2006). Educational Psychologist, 42(2), 99-107. https://doi. org/10.1080/00461520701263368.

Holliday, D. C. (2002). Jigsaw IV: Using student/teacher concerns to improve jigsaw III. https://archive.org/details/ ERIC_ED465687.

Jansen, J. D. (1998). Curriculum reform in South Africa: A critical analysis of outcomesbased education. Cambridge Journal of Education, 28(3), 321-331. https://doi. org/10.1080/0305764980280305.

Jansoon, N., Somsook, E., \& Coll, R. K. (2008). Thai undergraduate chemistry practical learning experiences using the jigsaw IV method. Journal of Science and Mathematics Education in Southeast Asia, 31(2), 178-200.

Joyce, B., Weil, M., \& Calhoun, E. (2009). Models of teaching $\left(8^{\text {th }} \mathrm{ed}\right)$. Boston, MA: Pearson. 
Leikin, R., \& Zaslavsky, O. (1999). Cooperative learning in mathematics. The Mathematics Teacher, 92(3), 240-246. http://www.jstor. org/stable/27970923.

Li, W. (2012). Critical analysis of cooperative learning in Chinese ELT context. Journal of Language Teaching and Research, 3(5), 961-966. https://doi.org/10.4304/ jltr.3.5.961-966.

Maceiras, R., Cancela, A., Urréjola, S., \& Sánchez, A. (2011). Experience of cooperative learning in engineering. European Journal of Engineering Education, 36(1), 13-19. https://doi.org/ 10.1080/03043797.2010.518232.

Mengduo, Q., \& Xiaoling, J. I. N. (2010). Jigsaw strategy as a cooperative learning technique: Focusing on the language learners. Chinese Journal of Applied Linguistics, 33(4), 113-125.

Oludipe, D., \& Awokoy, J. O. (2010). Effect of cooperative learning teaching strategy on the reduction of students' anxiety for learning chemistry. Turkish Science Education, 7(1), 30-36. http://www.tused. org/index.php/tused/article/view/501/431.

Paas, F., Tuovinen, J. E., Tabbers, H., \& van Gerven, P. W. M. (2003). Cognitive load measurement as a means to advance cognitive load theory. Educational Psychologist, 38(1), 63-71. https://doi. org/10.1207/S15326985EP3801_8.

Perkins, D. V., \& Saris, R. N. (2001). A “jigsaw classroom" technique for undergraduate statistics courses. Teaching of Psychology, 28(2), 111-113. https://doi.org/10.1207/ S15328023TOP2802_09.

Permendikbud RI 2018 No. 37. Perubahan atas peraturan Menteri Pendidikan dan Kebudayaan No 24 Tahun 2016 tentang kompetensi inti dan kompetensi dasar pelajaran pada Kurikulum 2013 pada pendidikan dasar dan pendidikan menengah. [Amandment on the rule of Minister of Education and Culture No 24 Year 2016 about the core competency and basic competency in the Curriculum 2013 at the elementary and secondary education level].

Persky, A. M., \& Pollack, G. M. (2009). A hybrid jigsaw approach to teaching renal clearance concepts. American Journal of Pharmaceutical Education, 73(3), 1-6. https://doi.org/10.5688/aj730349.

Rika, M. Y. (2017). The implementation of jigsaw technique in teaching speaking of the eighth grade students at the second semester of SMP Negeri 1 Krui in 2015/2016 academic year (Undergraduate thesis, UIN Raden Intan Lampung). http:// repository.radenintan.ac.id/1376/.

Slavin, R. E. (1987). Cooperative learning: Student teams, what research says to teachers $\left(2^{\text {nd }}\right.$ ed). Washington, DC: National Education Association.

Stahl, R. (1994). Cooperative learning in social studies: A handbook for teachers. Menlo Park, CA: Addison-Wesley.

Sweller, J., Ayres, P., \& Kalyuga, S. (2011). Cognitive load theory. New York, NY: Springer.

Tombak, B., \& Altun, S. (2016). The effect of cooperative learning: University example. Eurasian Journal of Educational Research, 16(64), 173-196. https://doi. org/10.14689/ejer.2016.64.10.

Ural, E., Ercan, O., \& Gençoğlan, D. M. (2017). The effect of jigsaw technique on 6th graders' learning of force and motion unit and their science attitudes and motivation. Asia-Pacific Forum on Science Learning and Teaching, 18(1), 1-21. https://www. eduhk.hk/apfslt/download/v18_issue1_ files/ural.pdf.

Zubaidah, S., Corebima, A. D., Mahanal, S., \& Mistianah, M. (2018). Revealing the relationship between reading interest and critical thinking skills through remap GI and remap jigsaw. International Journal of Instruction, 11(2), 41-56. https://doi. org/10.12973/iji.2018.1124a. 


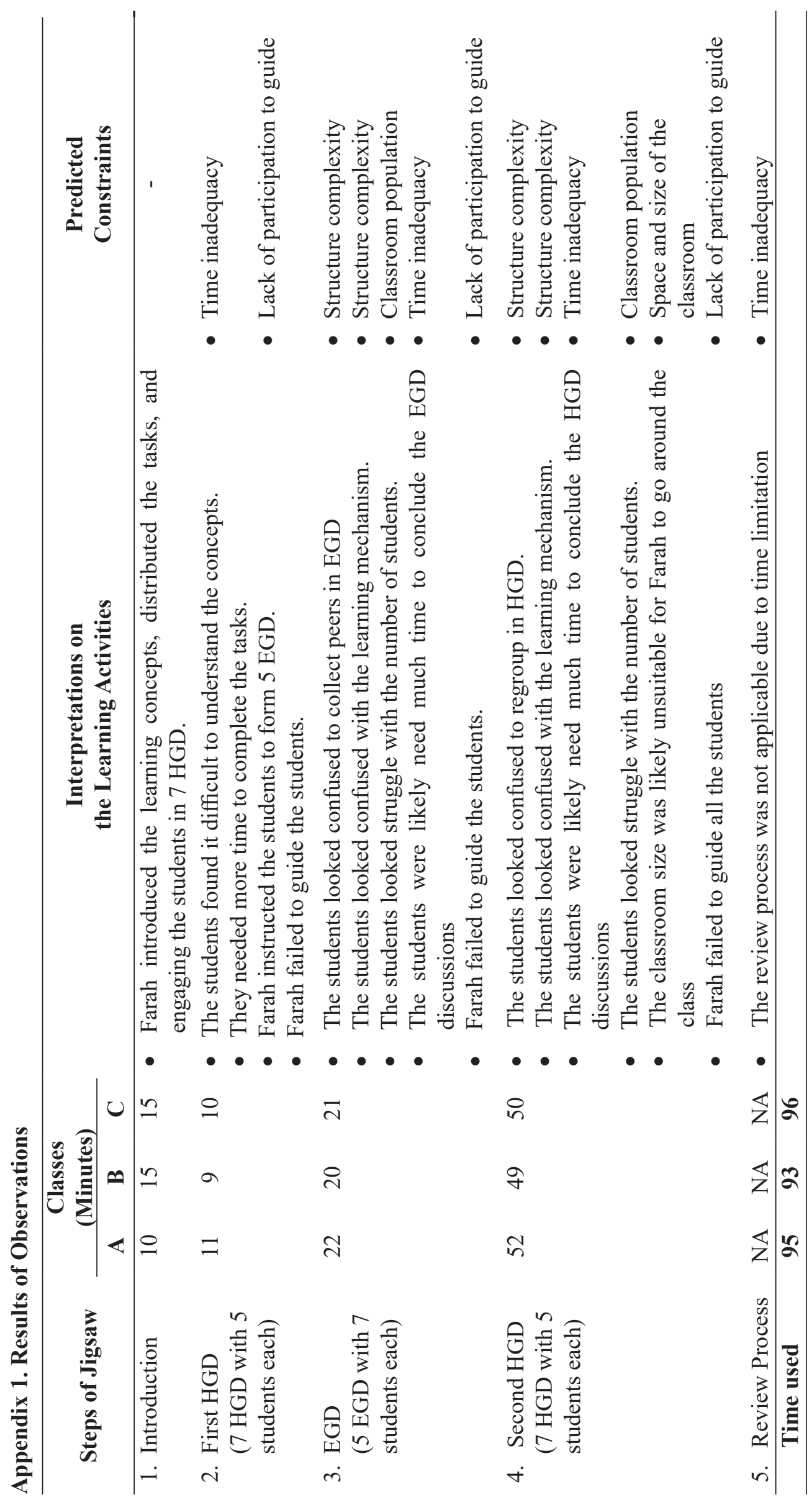

